\title{
Oral chronic graft-versus-host disease: analysis of dendritic cells subpopulations ${ }^{*}$
}

\author{
Clara Marino Espricigo Botari ${ }^{1}$ \\ Mair Pedro de Souza ${ }^{1}$ \\ Ana Gabriela Salvio ${ }^{1,2}$
}

\author{
Adauto José Ferreira Nunes ${ }^{1}$ \\ Érica Sinara Lenharo Orti-Raduan ${ }^{1}$
}

DOI: http://dx.doi.org/10.1590/abd1806-4841.20142464

\begin{abstract}
The graft-versus-host disease is the major cause of morbidity and mortality in patients who have undergone hematopoietic stem cell transplantation. Aiming at contributing to the understanding of the role of myeloid and plasmacytoid dendritic cells, and natural killer cells in chronic graft-versus-host disease, we examined biopsies of jugal mucosa of 26 patients with acute myeloid leukemia who had undergone allogenic hematopoietic stem cell transplantation. Half of these patients developed oral chronic graft-versus-host disease. Microscopic sections were immunohistochemically stained for anti-CD1a, anti-CD123 and anti-CD56. We calculated the number of immunostained cells in the corium per square millimeter and applied the Mann-Whitney test. Results showed a statistically significant increase of myeloid dendritic cells $(\mathrm{CD} 1 \mathrm{a}+; \mathrm{p}=0,02)$ and natural killer cells $(\mathrm{CD} 56 ; \mathrm{p}=0,04)$ in patients with oral chronic graft-versus-host disease. CD123 immunostaining showed no statistical difference between groups. It was concluded that myeloid dendritic cells and natural killer cells participate in the development of oral chronic graft-versus-host disease.
\end{abstract}

Keywords: Dendritic cells; Chronic disease; Graft-versus-host disease; Mouth mucosa

\section{INTRODUCTION}

Graft-versus-host disease (GVHD) is the major cause of morbidity and mortality in patients who have undergone allogeneic bone marrow transplantation. It is a syndrome with various clinical, pathological and immunological manifestations, attributed to the action of activated $\mathrm{T}$ lymphocytes from an HLAincompatible donor in an immunocompromised recipient. ${ }^{1}$ GVHD occurs when T cells from the transplanted bone marrow recognize histocompatibility complex antigens of the host as foreign, proliferate and attack recipient tissues. In order for GVHD to occur, the donor graft must contain immunologically competent cells and the host must be incapable of mounting an effective immune response to destroy the transplanted cells. In addition, the host must express tissue antigens that are not present in the transplant donor. ${ }^{1}$ Risk factors for the development of GVHD are present both in the donor and in the recipient. Recipient risk factors are: age over 50 years, type of pre-transplant conditioning regimen, use of radiation and type of prophylaxis used. ${ }^{2}$ Risk factors relat- ed to the donor are: gender disparity between donor and recipient (e.g., female donor and male recipient), number of previous pregnancies, HLA compatibility, and the source of cells used. ${ }^{2}$ The assessment of risk conditions usually guides the choice of the prophylaxis method. ${ }^{2,3}$

GVHD may be classified into two forms, according to the chronology, and to clinical and histological findings: acute (aGVHD) and chronic (cGVHD).

The oral cavity is affected in both forms of GVHD, and oral morbidity is highly significant. ${ }^{4}$ According to the current classification proposed by the National Institute of Health (NIH), the presence of oral lichenoid lesions, hyperkeratotic plaques and restricted mouth opening are diagnostic characteristics of chronic GVHD, i.e., these characteristics are sufficient for diagnostic confirmation of GVHD, sparing the histological analysis. Manifestations of xerostomia, mucocele, atrophy and ulcers require histological confirmation. ${ }^{5}$

\footnotetext{
Received on 20.01.2013.

Approved by the Advisory Board and accepted for publication on 19.05.2013.

* Study conducted at the Hospital Fundação Amaral Carvalho - Jaú (SP), Brazil.

Conflict of interest: None

Financial funding: None 
The use of monoclonal antibodies in immunohistochemical techniques has been common in studies investigating subpopulations of lymphoid cells involved in oral GVHD, including dendritic cells. ${ }^{6-8}$

Dendritic cells (DC) constitute a family of antigen-presenting cells derived from hematopoietic progenitors in the bone marrow, capable of interacting with $\mathrm{T}$ and $\mathrm{B}$ lymphocytes and modulating their responses. DC were first described in 1973 by Steinman and Cohn from cells isolated from the spleen. They are called dendritic because of their morphology. ${ }^{9}$ Two distinct lineages of dendritic cells have been described in humans: myeloid dendritic cells, which express CD1a, and are derived from monocytes and macrophages; and plasmacytoid dendritic cells, which express CD123 (interleukin-3 receptor alpha chain), and have a lymphoid origin. The role of plasmacytoid dendritic cells in graft-versus-host disease remains uncertain and their in vivo function as antigen-presenting cells remains controversial. ${ }^{10}$ It has been demonstrated in mice that these cells may be able to activate alloreactive $\mathrm{T}$ cells and cause GVHD. ${ }^{11}$ Conversely, depletion of plasmacytoid dendritic cells from bone marrow grafts resulted in an acceleration of GVHD mortality. ${ }^{12}$ Plasmacytoid dendritic cells have special implications in immunological recovery in the period shortly after stem cell transplantation. Their interaction with NK cells (natural killer) determines important responses for the induction of tolerance to prevent GVHD, and an antitumor effect to prevent relapse. ${ }^{13}$

There are no reports about the involvement and distribution pattern of these cells in lesions of oral chronic GVHD. Thus, such research could be a promising avenue for better understanding the pathogenesis and finding new therapeutic approaches to GVHD.

\section{OBJECTIVE}

The present study aimed to evaluate the presence and concentration of dendritic cells and NK cells, immunohistochemically stained for the primary antiCD123, anti-CD1a and anti-CD56 antibodies, respectively, in oral mucosa fragments of patients who had undergone hematopoietic stem cell transplantation, with and without chronic GVHD.

\section{METHODS}

This study was approved by the Research Ethics Committee (REC) of the Amaral Carvalho Hospital Foundation, Jaú - SP, Brazil, under No. 141/10.

Punch biopsies of oral mucosa of patients from the Amaral Carvalho Hospital who had undergone hematopoietic stem cell transplantation were obtained from the Anatomical Pathology Services file in the period 2009-2011. Two groups were selected: Group 1: oral mucosa biopsies of 13 patients with acute myeloid leukemia (AML) who had undergone allogeneic transplantation of bone marrow-derived hematopoietic stem cells from relative donors and developed chronic graft-versus-host disease, confirmed by clinical and microscopical examination. Group 2: oral mucosa biopsies from 13 patients with AML who underwent allogeneic transplantation of bone marrow-derived hematopoietic stem cells from relative donors, and did not develop chronic graftversus-host disease in any organ (confirmed by clinical and microscopical examination) throughout the entire period of post-transplantation immunosuppressive treatment.

\section{IMMUNOHISTOCHEMISTRY STAINING}

3 - $\mu$ m-thick serial microscopic sections fixed in buffered formalin were obtained and prepared for immunohistochemical staining. The sections prepared by microtome cutting were placed in a histological water bath and deposited on previously silanized slides (organosilane, Sigma, Code A3648). Slides with sections were dried at $60^{\circ} \mathrm{C}$ for 5 hours. Next, sections were deparaffinized and placed for hydration in 3 vats containing xylene for 10 minutes each, then in 4 vats containing absolute alcohol (99.5\%) for 1 minute each, and finally left in distilled water for 3 minutes. Immunohistochemical protocols were then performed using the streptavidin-biotin peroxidase technique (LSAB - Dako) with anti-CD123 antibody, and the dextran-polymer technique (Envision) with anti-CD1a antibody and anti-CD56 antibody. Antigen retrieval was performed in a citrate-buffer solution, $\mathrm{pH}$ 6.2, Target (Dako-K-035) using an autoclave. Incubation with anti-CD123 monoclonal antibody (1:200 dilution; clone 6H6; e-Bioscience) was carried out in appropriate diluent (Dako Code S3022) for 30 minutes at room temperature. Incubation with anti-CD1a monoclonal antibody (1:50 dilution; clone 010, Dako) and anti-CD56 antibody (1:100 dilution; NCAM clone-1B6; Biocare Medical) was carried out in appropriate diluent (Dako Code S3022 ) for 30 minutes at room temperature.

\section{QUANTIFICATION OF CELLS}

Dendritic cells and NK cells of the corium were quantified in the subepithelial region of the connective tissue by using a computerized image capturing system. As células dendríticas e células NK do córion foram quantificadas na região do tecido conjuntivo subepitelial.

Cell counting was performed by two investigators, without knowledge of the groups to which the samples of oral mucosa belonged.

The number of immunostained dendritic cells and NK cells $/ \mathrm{mm}^{2}$ in the corium of the oral mucosa was calculated for each surgical specimen by dividing the average of dendritic cells present in the 10 fields 
examined by the area covered in each specimen. Images were captured by an image processing and analysis system (Image Lab - Softium Informatica Ltda - ME).

\section{STATISTICAL ANALYSIS}

The Mann-Whitney test was applied for the analysis of immunostaining with anti-CD1a antibody and anti-CD56 antibody, because data did not show a normal distribution. Fisher's test was used to analyze the correlation between the following variables: sex, age, D+ (post-HSCT days), immunosuppressive therapy regimen and relationship between donor-recipient gender.

\section{RESULTS}

Figure 1 shows histological findings typical of patients with chronic GVHD, such as chronic lymphocytic inflammatory infiltrate in band-like pattern, and apoptotic bodies.

The analysis between groups with and without GVHD showed a statistically significant increase in CD1a $(p=0.022)$ and CD56 cells $(p=0.04)$ cells. Immunostaining for CD123 was negative both in cases with and without GVHD (Figures 2, 3, 4, Graph 1 and Table 1).

The distribution of patients in two groups according to sex and age at the time of biopsy, and in different groups according to disease diagnosis, date of biopsy in relation to post-transplant day $(\mathrm{D}+)$, current immunosuppressive therapy and relationship between donor-recipient gender can be seen in the table below.

In the analysis of the variable "gender", there was a predominance of males $(p=0.69)$ in both groups (with and without chronic GVHD) among the patients in our sample. The mean age of patients in both groups was between 21 and 40 years $(p=0.46)$. In the group with chronic GVHD, patients underwent biopsy 100 to 200 days after transplantation. In the group without chronic GVHD, patients underwent biopsy before 100 years after transplantation $(p<0.01)$. Immunossuppressive therapy was conducted for at least 100 days after transplantation in both groups

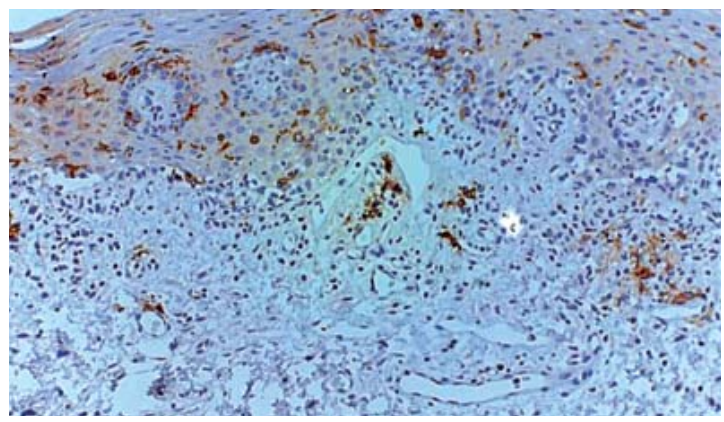

FIGURE 2: CD1a immunostaining of myeloid dendritic cells of the oral mucosa of a transplanted patient with chronic GVHD (20X)

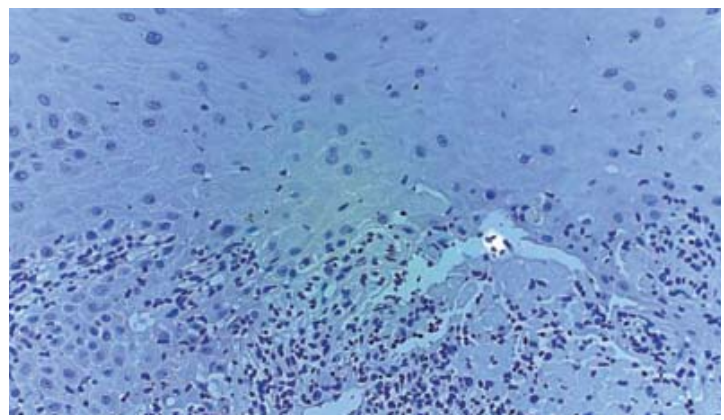

FIGURE 3: Absence of immunostaining with anti-CD123 antibody for plasmacytoid dendritic cells in oral mucosa of a patient with chronic GVHD (20X)

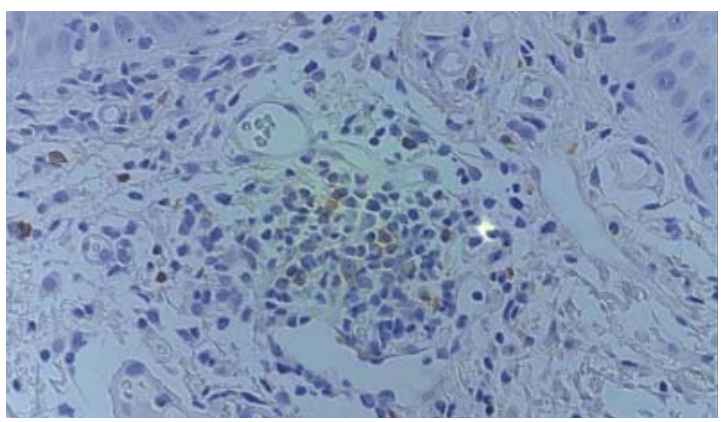

FiguRE 4: CD56 immunostaining of NK cells in the oral mucosa of a transplanted patient with chronic GVHD. (40X)
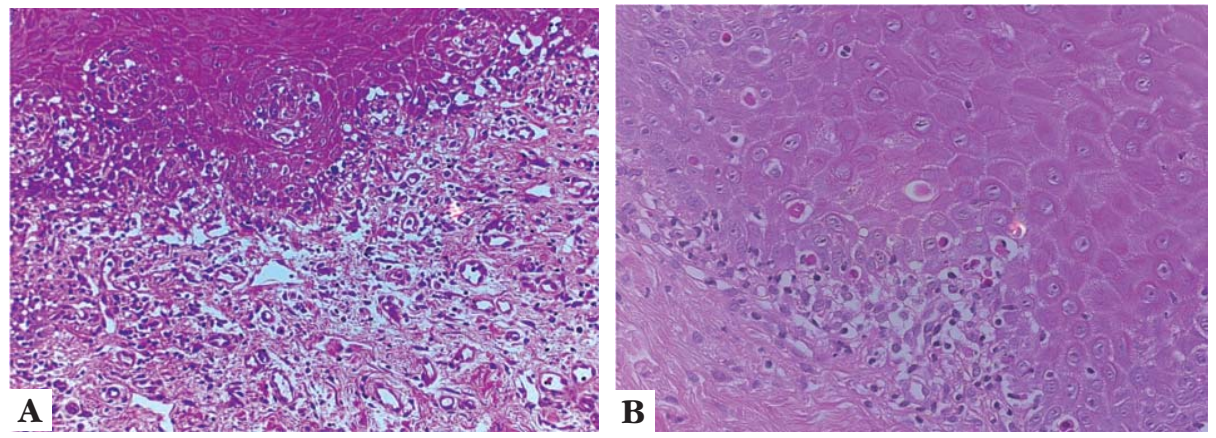

Figure 1: A. Oral mucosa of a transplanted patient with chronic GVHD showing lymphocytic infiltrate attacking the dermo-epidermal junction, and areas of apoptosis. $(\mathrm{EH}, 20 \mathrm{X})$; B. Detail of the area with apoptosis. (HE, 40X) 
$(p=0.32)$. Regarding the variable "relationship between donor-recipient gender", there was a higher predominance of male donors and recipients $(\mathrm{p}=0.92)$ in both groups. Patients were selected according to the diagnosis of the underlying disease (Acute myeloid leukemia) in $100 \%$ of the sample, in the groups with and without CGVHD (Table 1).

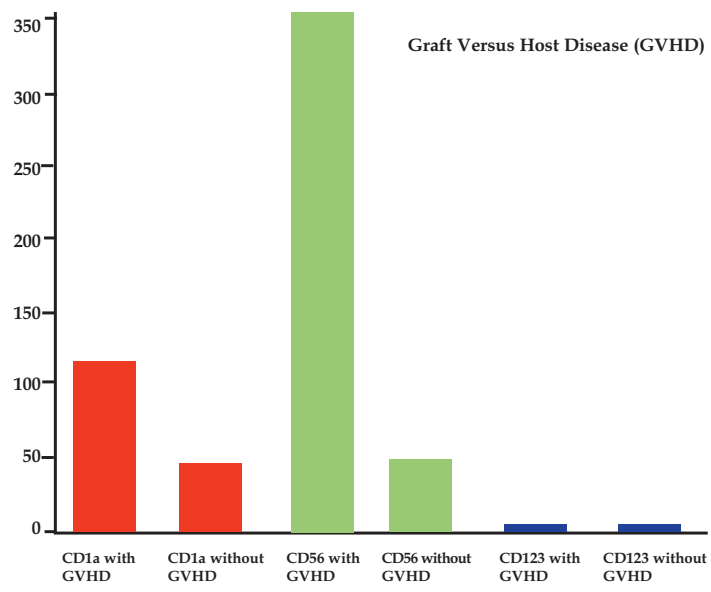

GRAPH 1: Number of cells per square milliliter found in the different groups
Data correlation analysis revealed differences between groups and variables. However, these findings (despite the differences and the absence of statistical correlation) do not interfere with the study result because the underlying disease - acute myeloid leukemia - was the criterion chosen to define and standardize the sample. Due to this standardization in the choice of the underlying disease, patients in both groups (with and without chronic GVHD) had the same conditioning regimens before HSCT. These two factors together homogenize the sample according to their immunohistochemical results. The variable D + had $p<0.01$, because patients undergo biopsy for monitoring of HSCT on dates pre-established by the transplantation unit of the Amaral Carvalho Hospital Jau-SP, Brazil.

\section{DISCUSSION}

This study quantitatively evaluated subpopulations of myeloid dendritic cells (CD1a+), plasmacytoid dendritic cells (CD123+) and NK cells (CD56+) of the corium of the oral mucosa of transplanted patients with GVHD. The selection of individuals with the same underlying disease (acute myeloid leukemia), no large variations in age and allogenic transplantation among relatives was important in order to homogenize the study sample by providing similar antigenic conditions.

TABLE 1: Characteristics of included articles according to dermatological condition and medications used

\begin{tabular}{|c|c|c|c|c|c|}
\hline \multirow[t]{2}{*}{ Characteristics } & \multicolumn{2}{|c|}{ With cGVHD } & \multicolumn{2}{|c|}{ Without cGVHD } & \multirow[b]{2}{*}{$\mathbf{P}$} \\
\hline & $\mathbf{n}$ & $\%$ & $\mathbf{n}$ & $\%$ & \\
\hline Gender & & & & & 0.69 \\
\hline Male & 7 & 53.8 & 9 & 69.2 & \\
\hline Female & 6 & 46.2 & 4 & 30.8 & \\
\hline Age & & & & & 0.46 \\
\hline$\leq 20$ years & 1 & 7.7 & 1 & 7.7 & \\
\hline 21 to 40 years & 8 & 61.5 & 10 & 76.9 & \\
\hline$\geq 40$ years & 4 & 30.8 & 2 & 15.4 & \\
\hline Diagnosis & & & & & \\
\hline AML & 13 & 100 & 13 & 100 & \\
\hline D+ (Days) & & & & & 0.01 \\
\hline$\leq 100$ & 2 & 15.4 & 12 & 92.3 & \\
\hline $101-200$ & 8 & 61.5 & 1 & 7.7 & \\
\hline$\geq 201$ & 3 & 23.1 & 0 & 0 & \\
\hline Immunossuppressive Therapy & & & & & 0.32 \\
\hline Yes & 9 & 69.2 & 12 & 92.3 & \\
\hline No & 4 & 30.8 & 1 & 7.7 & \\
\hline Recipient/Donor (Relatives) & & & & & 0.92 \\
\hline $\mathrm{M} / \mathrm{M}$ & 6 & 46.2 & 7 & 53.8 & \\
\hline $\mathrm{M} / \mathrm{F}$ & 2 & 15.3 & 2 & 15.4 & \\
\hline $\mathrm{F} / \mathrm{F}$ & 5 & 38.5 & 4 & 30.8 & \\
\hline
\end{tabular}

$\mathbf{n}=$ number of patients, D+, days after transplantation of hematopoietic stem cells, on which the biopsy was performed.; M: male; F: female 
The lymphocytic inflammatory infiltrate found in biopsies of corium of oral mucosa in this study is a characteristic feature of GVHD, because its occurrence is associated with the presence of activated T lymphocytes from the transplanted bone marrow, which recognize the histocompatibility complex antigens of the host as foreign, proliferate and attack recipient tissues. ${ }^{14}$

Unlike most studies of the literature, which focus on $\mathrm{CD} \mathrm{a}^{+} / \mathrm{CD} 207^{+}$intraepithelial dendritic cells of the skin - the Langerhans cells - the focus in this study are the cells of the corium of the oral mucosa. We found little reported data on the subpopulations of dermal myeloid dendritic cells and plasmacytoid dendritic cells. ${ }^{15}$

This study showed a statistically significant increase of CD1a + cells $/ \mathrm{mm}^{2}$ in the corium of vindividuals without the disease. This result was similar to other studies that analyzed dendritic cells in the oral mucosa of patients with GVHD, but were restricted to the investigation of Langerhans cells. ${ }^{8}$

One possible explanation for this significant increase in the subpopulation of myeloid dendritic cells, would be the production of specific chemokines responsible for the recruitment of myeloid precursors from the bone marrow via peripheral blood. The inflammatory process characteristic of GVHD would be induced by an alloreaction of donor $\mathrm{T}$ cells against host residual dendritic cells. ${ }^{16}$ This process would stimulate the secretion of chemokines and consequently establish a local gradient, resulting in the chemical attraction of CD34 + (or more differentiated) haematopoietic precursors of LCs, from the transplanted bone marrow. The proliferation of dendritic cells in situ, although described only in healthy tissues, cannot be discarded. ${ }^{17,16}$ The myeloid dendritic cells found in the corium could represent a reserve for posterior migration to the epithelium.

There is a discordant report in the literature. Deguchi et al, 2002, assessed acute and chronic skin GVHD and showed a reduced number of dermal cells $\mathrm{CD} 1 \mathrm{a}+.{ }^{6}$ One possible explanation for this discrepancy (other than intrinsic differences in the tissue under study) are that diagnostic criteria for cGVHD are not well established. The chronological criterion $(>100$ days) is used for inclusion of cases.
Compared to the control group, a statistically significant increase in NK cells $/ \mathrm{mm}^{2}$ could be seen in the inflammatory infiltrate of the corium of the oral mucosa of patients with GVHD.

This could suggest the involvement of other activating factors, since plasmacytoid dendritic cells (well-known activators of NK cells) were not detected.

The results of this study showed the absence of CD123 + cells in the corium of the oral mucosa of patients with and without GVHD. This speaks against the participation of the lineage of plasmacytoid dendritic cells in the pathogenesis of chronic GVHD. In contrast, in a study conducted in the human skin by Weiss et al., 2007, a significant dermal infiltration (>20 cells per $\mathrm{mm}^{2}$ ) of plasmacytoid dendritic cells was detected in patients with GVHD when compared to the reaction to the drug where the infiltrate was predominantly of myeloid lineage.

Studies have shown the absence of immunostaining for CD123+ plasmacytoid dendritic cells in normal skin, psoriasis and polymorphic light eruption. ${ }^{15,18,19}$ However, in skin lesions of autoimmune diseases such as lupus erythematosus and dermatomyositis, its expression is increased..$^{20}$

Since plasmacytoid dendritic cells are wellknown activators of NK cells, their participation in the pathogenesis of the disease cannot be totally discarded, either at very early stages or in very small numbers. Detection may be compromised by the low sensitivity of antibodies commercially available today.

Future studies are necessary to exclude other NK cells activating factors, as well as confirm the absence of plasmacytoid dendritic cells in the corium of the oral mucosa of patients who have undergone hematopoietic stem cell transplantation and developed chronic graft-versus-host disease.

\section{CONCLUSION}

The present study confirmed the increase of $\mathrm{CD} 1 \mathrm{a}+$ and NK cells in the corium of the oral mucosa of patients with chronic GVHD. The absence of CD123 expression does not exclude its participation in the chronic GVHD process. Further studies with larger numbers of cases and comparing the expression of these markers in acute GVHD are needed in order to better understand the pathophysiology of GVHD. 


\section{REFERENCES}

1. Silva MM, Bouzas LFS, Filgueira A. Tegumentary manifestations of graft-versushost disease in bone marrow transplantation recipients. An Bras Dermatol 2005;80:69-80.

2. Pavletic SZ, Fowler DH. Are we making progress in GVHD prophylaxis and treatment? Hematology Am Soc Hematol Educ Program. 2012;2012:251-64.

3. Ruutu T, van Biezen A, Hertenstein B, Henseler A, Garderet L, Passweg J,et al Prophylaxis and treatment of GVHD after allogeneic haematopoietic SCT: a survey of centre strategies by the European Group for Blood and Marrow Transplantation. Bone Marrow Transplant. 2012;47:1459-64.

4. Filipovich AH. Diagnosis and manifestations of chronic graft-versus-host disease. Best Pract Res ClinHaematol. 2008;21:251-7.

5. Filipovich AH, Weisdorf D, Pavletic S, Socie G, Wingard JR, Lee SJ, et al. Nationa Institutes of Health consensus development project on criteria for clinical trials in chronic graft-versus-host disease: I. Diagnosis and staging working group report. Biol Blood Marrow Transplant. 2005;11:945-56.

6. Deguchi M, Aiba S, Ohtani H, Nagura H, Tagami H.Comparison of the distribution and numbers of antigen-presenting cells among T-lymphocyte-mediated dermatoses: $\mathrm{CD1a}+$, factor XIIla +, and CD68 + cells in eczematous dermatitis, psoriasis, lichen planus and graft-versus-host disease. Arch Dermatol Res. 2002;294:297-302.

7. Ferrara JL. Pathogenesis of acute graft-versus-host disease: cytokines and cellular effectors. J Hematother Stem Cell Res. 2000;9:299-306.

8. Orti-Raduan ES, Nunes AJ, Oliveira DT, Lara VS, Taveira LA.Quantitative analysis of Langerhans' cells in oral chronic graft-vs.-host disease.J Oral Pathol Med. 2009;38:132-7.

9. Steinman RM, Cohn ZA. Identification of a novel cell type in peripheral lymphoid organs of mice. I. Morphology, quantitation, tissue distribution. J Exp Med. 1973;137:1142-62.

10. Rossi M, Arpinati M, Rondelli D, Anasetti C. Plasmacytoid dendritic cells: do they have a role in immune responses after hematopoietic cell transplantation? Hum Immunol. 2002;63:1194-200.

11. Koyama M, Hashimoto D, Aoyama K, Matsuoka K, Karube K, Niiro H,et al. Plasmacytoid dendritic cells prime alloreactive $T$ cells to mediate graft-versus-host disease as antigen-presenting cells. Blood. 2009;113:2088-95.

12. Banovic T, Markey KA, Kuns RD, Olver SD, Raffelt NC, Don AL, et al. Graft-versushost disease prevents the maturation of plasmacytoid dendritic cells. J Immunol. 2009;182:912-20.

13. Chklovskaia E, Nowbakht P, Nissen C, Gratwohl A, Bargetzi M, Wodnar-Filipowicz A. Reconstitution of dendritic and natural killer-cell subsets after allogeneic stem cell transplantation: effects of endogenous flt3 ligand. Blood. 2004;103:3860-8.

14. Soares AB, Faria PR, Magna LA, Correa ME, de Sousa CA, Almeida OP, et al. Chronic GVHD in minor salivary glands and oral mucosa: histopathological and immunohistochemical evaluation of 25 patients. J Oral Pathol Med. 2005;34:368-73.

15. Zaba LC, Krueger JG, Lowes MA. Resident and "inflammatory" dendritic cells in human skin.J InvestDermatol. 2009;129:302-8.

16. Merad M, Manz MG, Karsunky H, Wagers A, Peters W, Charo I, et al. Langerhans cells renew in the skin throughout life under steady-state conditions. Nat Immunol. 2002;3:1135-41.

17. Merad M. Ontogeny of Lagerhans cells and graft versus host disease. Adv Exp Med Biol. 2005;560:115-23.

18. Ebner S, Ehammer Z, Holzmann S, Schwingshackl P, Forstner M, Stoitzner P, et al Expression of $\mathrm{C}$-type lectin receptors by subsets of dendritic cells in human skin. Int Immunol. 2004;16:877-87.

19. Wackernagel A, Massone C, Hoefler G, Steinbauer E, Kerl H, Wolf P. Plasmacytoid dendritic cells are absent in skin lesions of polymorphic light eruption. Photodermatol Photoimmunol Photomed. 2007;23:24-8.

20. McNiff JM, Kaplan DH. Plasmacytoid dendritic cells are present in cutaneous dermatomyositis lesions in a pattern distinct from lupus erythematosus. J Cutan Pathol. 2008;35:452-6.

\author{
MAILING ADDRESS: \\ Ana Gabriela Salvio \\ Rua Dona Silvéria, 150 \\ 17210-080 - Jaú - SP \\ Brazil \\ E-mail: gasalvio@hotmail.com
}

How to cite this article: Botari CME, Nunes AJF, Souza MP, Orti-Raduan ESL, Salvio AG. Oral chronic graft-versus-host disease: analysis of dendritic cells subpopulations. An Bras Dermatol. 2014;89(4):632-7. 